\title{
Cytotoxicity evaluation of a Thai herb using tetrazolium (MTT) and sulforhodamine B (SRB) assays
}

La-ongthong Vajrabhaya ${ }^{1}$ and Suwanna Korsuwannawong ${ }^{2^{*}}$

\begin{abstract}
Background: Various assays are used to evaluate the cytotoxic effect of chemicals on cultured cells. The sulforhodamine B (SRB) colorimetric assay is based on the ability of the SRB dye to bind basic amino acid residues on proteins. In contrast, the MTT (dimethylthiazol-diphenyltetrazolium bromide) colorimetric assay is based on mitochondrial uptake and succinate dehydrogenase reduction of soluble, yellow, MTT tetrazolium salt to an insoluble blue MTT formazan product. The aim of this study was to evaluate the cytotoxicity of a Thai herb by comparing MTT and SRB assay results.

Methods: Mouse fibroblast (L929) cells were exposed to $0.01,0.1,0.25$, and $0.5 \%(w / v)$ of a Thai herb in a 96-cluster well culture plate for $24 \mathrm{~h}$. Cell viability after exposure to the Thai herb was determined by MTT and SRB assays in separate tissue culture plates. The two assays were compared using intra-class correlation coefficient (ICC) analysis.

Results: There were no significant differences between the two cytotoxicity assays $(p>0.05)$. The ICC values showing the agreement of the two assays in the negative and positive control groups and Thai herb concentrations of $0.01,0.1,0.25$, and $0.5 \%$ were 0.93 and 0.99 and $0.53,0.51,0.95$, and 0.98 , respectively.

Conclusions: In general, the MTT and SRB assays performed similarly, exhibiting moderate to excellent correlation in the evaluation of the cytotoxicity of a Thai herb.
\end{abstract}

\section{Background}

The MTT (dimethylthiazol-diphenyltetrazolium bromide) colorimetric assay determines the functional state of mitochondria, indicating cell viability. A mitochondrial dehydrogenase enzyme in living cells reduces yellow tetrazolium MTT salt to blue MTT formazan, which is precipitated in uninjured cells (Edmondson et al. 1998).

The MTT assay is the most widely used cell viability assay, and several modifications of the original method have been described (Mosmann 1983). However, the amount of MTT is not linear with cell number at high cell densities (Ruben and Neubauer 1987; Plumb et al. 1989). Cell lines under a number of conditions have large intra-assay and inter-assay variations. Intra-assay variations refer to variations in results within a dataset obtained from one experiment, while inter-assay variations refer to the precision of results among different

\footnotetext{
* Correspondence: Suwanna.aut@mahidol.ac.th

${ }^{2}$ Research Office, Faculty of Dentistry, Mahidol University, Yothi Road,

Rajthawee District, Bangkok 10400, Thailand

Full list of author information is available at the end of the article
}

assays (Park et al. 1987). The sulforhodamine B (SRB) protein stain is used for in vitro chemosensitivity testing. The SRB assay appears to be more sensitive than the MTT assay, with a better linearity with cell number and higher reproducibility (Skehan et al. 1990; Rubenstein et al. 1990). These assays are relevant to medical devices and materials used in dentistry, as pre-clinical evaluations are necessary to establish the biocompatibility of all devices and materials. The International Organization for Standardization (ISO) 7405 (International Organization for Standardization; ISO 7405 2008) recommends that high priority be given to minimizing the use of animals in the biological testing of materials. As scientific knowledge advances the understanding of basic mechanisms, an in vitro model that simulates an in vivo test or clinical use, which may yield equally relevant information, is advocated. A cell culture assay is one method of choice for toxicity screening. MTT, SRB, and neutral red uptake (NRU) assays are widely used for cytotoxic screening evaluation of dental agents and materials. MTT was used in both 


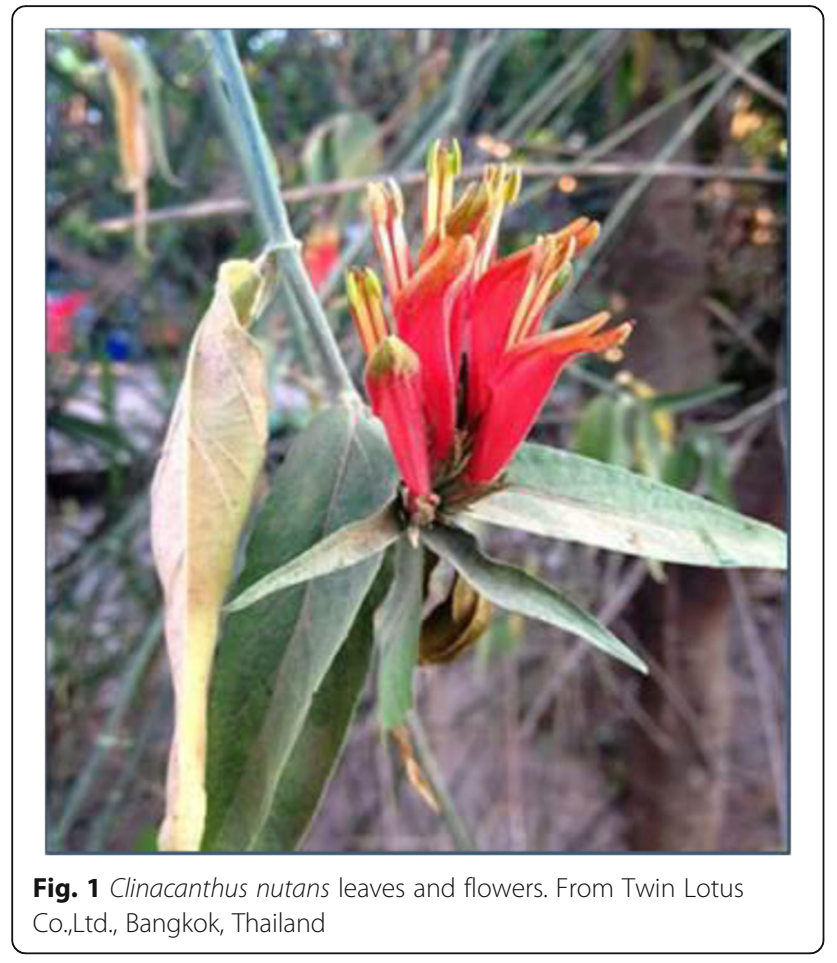

static and dynamic (perfusion condition) statuses of biocompatible assessment of various dentine-bonding agents (Vajrabhaya et al. 2003a; Vajrabhaya et al. 2009); NRU was used to assess the optimal time of conditioned medium storage for the cell survivability of an avulsed tooth (Vajrabhaya et al. 2003b); and SRB was used for biological screening of six endodontic sealers (Vajrabhaya et al. 1997). In general, the MTT and NRU assays perform similarly in the evaluation of the cytotoxicity of herbal plants, exhibiting a moderate to good correlation (Vajrabhaya and Korsuwannawong 2016).

Thus, the aim of this study was to evaluate the cytotoxicity of a Thai herb by comparing MTT and SRB assay results.

\section{Methods}

Test materials

We used a powder formulation of the Thai herb Phaya-Yor in Fig. 1, also known as Clinacanthus nutans (Twin Lotus Co., Ltd., Bangkok, Thailand). The color of the Thai herb powder is brown, with a maximum moisture of $8 \%$ and $\mathrm{pH}$ range of 6.00 to 8.00 . The minimum powder fineness can pass a No. 80 sieve with $75 \%$ efficiency. Clinacanthus nutans was dried in a hot air oven at $60{ }^{\circ} \mathrm{C}$ for $72 \mathrm{~h}$, ground into a fine powder using a Blender Panasonic MX-898 NC (Sripiboon Electric Co. Ltd., Bangkok, Thailand), and then filtered through a No. 80 sieve. A total of 0.2 g Clinacanthus nutans was weighed and mixed into $1 \mathrm{ml}$ Dulbecco's modified Eagle's medium (DMEM; Invitrogen, CA, USA) for a $20 \%$ $(w / v)$ solution. Then, the solution was incubated at $37^{\circ}$ $\mathrm{C}$ under $5 \% \mathrm{CO}_{2}$ for $24 \mathrm{~h}$. The stock solution of Clinacanthus nutans was centrifuged at $3500 \mathrm{rpm}$ for $10 \mathrm{~min}$, and the supernatant was diluted into $0.5,0.25$, 0.1 , and $0.01 \%(w / v)$ solutions.

As a positive control, the ISO 10993-5 (International Standard Organization; ISO 10993-5 2009) recommends using polyvinyl chloride (PVC; Hatano Research Institute, Food and Drug Safety Center, Kanagawa, Japan) films with a size of $3 \mathrm{~cm}^{2} / 2 \mathrm{ml}$ media. The films were soaked in $70 \%$ alcohol for $1 \mathrm{~min}$ for sterilization,

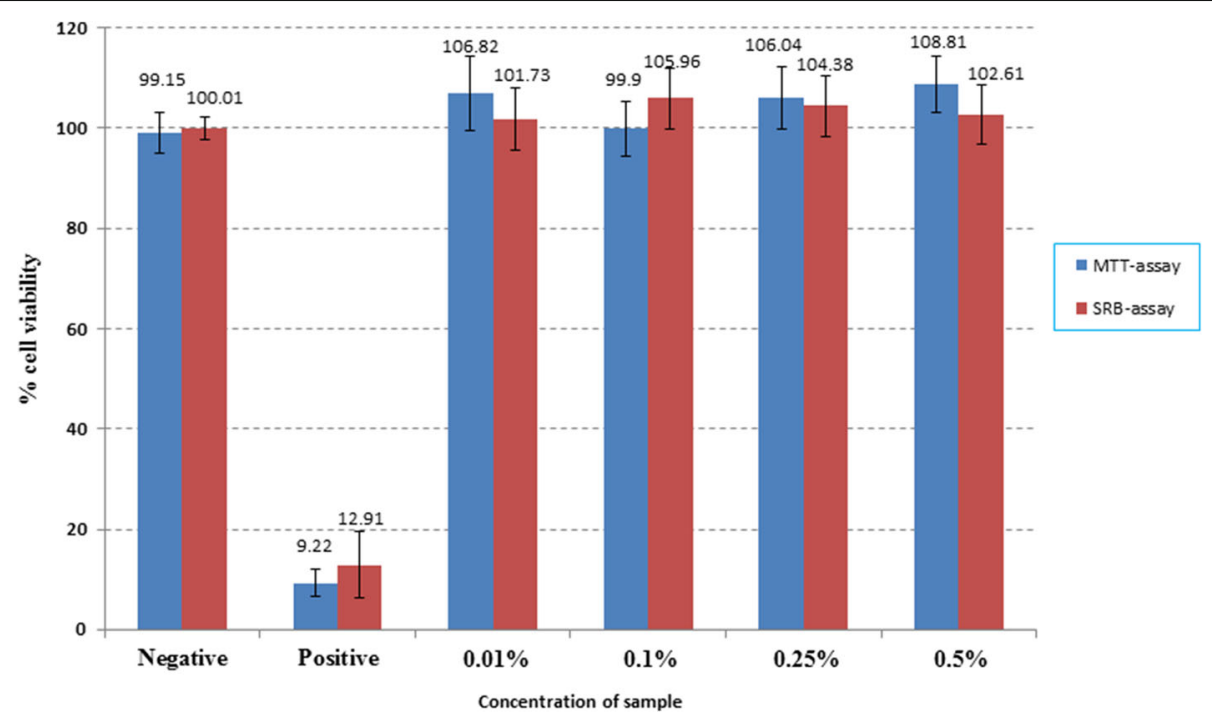

Fig. 2 Cell viability of L929 cells after exposure to the negative control, positive control, or different concentrations of a Thai herb 
washed in normal saline solution for $1 \mathrm{~min}$, and left to dry. Then, the films were inserted into DMEM and incubated at $37^{\circ} \mathrm{C}$ under $5 \% \mathrm{CO}_{2}$ for $24 \mathrm{~h}$ before testing.

As a negative control, the ISO 10993-5 (International Standard Organization; ISO 10993-5 2009) recommends using Thermanox plastic cover slips $\left(\mathrm{NUNC}^{\mathrm{m}}\right.$, Naperville, IL, USA) with a size of $6 \mathrm{~cm}^{2} / 2 \mathrm{ml}$ media. The Thermanox plastic cover slips were cut into small pieces, soaked in DMEM, and incubated under $5 \% \mathrm{CO}_{2}$ at $37^{\circ} \mathrm{C}$ for $24 \mathrm{~h}$ before testing.

\section{Cell culture procedure}

The target cells used in this experiment were a continuous line of mouse fibroblast L929 cells (NCTC clone 929; American Type Culture Collection (ATCC, VA, USA; ECACC No. 2869501)). The cells were maintained at $37^{\circ} \mathrm{C}$ under $5 \% \mathrm{CO}_{2}$ and $100 \%$ humidity in DMEM and supplemented with $10 \%$ fetal calf serum and antibiotics $(200 \mu \mathrm{l} /$ $\mathrm{ml}$ penicillin G, $200 \mu \mathrm{g} / \mathrm{ml}$ streptomycin, and $2 \mu \mathrm{g} / \mathrm{ml}$ fungizone). The medium was changed every other day. When the cells reached confluence, they were detached using $0.2 \%(w / v)$ trypsin and transferred to new culture flasks.

After sufficient growth for experimentation, the cells were trypsinized and plated in 96-cluster well culture plates at a concentration of $1 \times 10^{4}$ cells/well. Each well contained $100 \mu \mathrm{l}$ of cell suspension, and the plates were incubated for $24 \mathrm{~h}$ at $37^{\circ} \mathrm{C}$ under $5 \% \mathrm{CO}_{2}$ to obtain a monolayer culture. After $24 \mathrm{~h}$ of incubation, the old medium was removed from each well. Then, a 100- $\mu$ l eluted volume from the Clinacanthus nutans solution at concentrations of 0.01, 0.1, 0.25 , and $0.5 \%$; the positive control; or negative control was inserted into a 96-cluster well culture plate (8 wells/test material). Two 96-cluster well culture plates were separately prepared to evaluate cell viability using MTT and SRB assays. The experiments were repeated in triplicate. Following a 24-h incubation period at $37{ }^{\circ} \mathrm{C}$ under $5 \% \mathrm{CO}_{2}$, the cell viability of both plates was assessed.

\section{MTT assay}

The test materials were removed from each well of the first plate. Then, $50 \mu \mathrm{l}$ of MTT reagent $(5 \mathrm{mg} / \mathrm{ml})$ was added and incubated for $2 \mathrm{~h}$ at $37{ }^{\circ} \mathrm{C}$ in the $\mathrm{CO}_{2}$ incubator. The MTT solution was then discarded, and $100 \mu \mathrm{l}$ of isopropanol was added. The plates were placed on a shaker to solubilize the formations of purple crystal formazan. The absorbance was measured using a microplate reader at a wavelength of $570 \mathrm{~nm}$. The results were used to construct a graph of cell viability percentage against extract concentrations.

\section{SRB assay}

The SRB assay is used for cell density determination, based on the measurement of cellular protein content. The method described here has been optimized for the
Table 1 Criteria for grading the strength of assay agreement

\begin{tabular}{ll}
\hline Intra-class correlation coefficient & Strength of agreement \\
\hline$<0.25$ & Poor \\
$0.25-0.50$ & Fair \\
$0.50-0.75$ & Moderate \\
$0.75-0.90$ & Good \\
$>0.90$ & Excellent \\
\hline
\end{tabular}

toxicity screening of compounds to adherent cells in a 96-well format. After an incubation period, cell monolayers were fixed with $10 \%(\mathrm{wt} / \mathrm{vol})$ trichloroacetic acid and stained for $30 \mathrm{~min}$; then, excess dye was removed by washing the cells repeatedly with $1 \%$ (vol/vol) acetic acid. The protein-bound dye was dissolved in $10 \mathrm{mM}$ Tris base solution for optical density (OD) determination at $510 \mathrm{~nm}$ using a microplate reader.

Cell viability was expressed as a percentage of the control values. The intra-class correlation coefficient (ICC) and limits of agreement statistics (Bland and Altman 1986; Bland and Altman 1990; Bland and Altman 1995) were used to compare the scores (Deyo et al. 1991). The limits of agreement statistics were also used as a descriptive measure of agreement.

\section{Results}

The cytotoxic effects of the plant extracts on the viability of the L929 cell lines are presented as percent cell viability in Fig. 2. Values obtained from both SRB and MTT assays were comparable. Clinacanthus nutans extracts were non-cytotoxic, whereas the positive control exhibited the highest toxicity.

The ICC values for the agreement of the negative and positive control reactions of MTT and SRB assays were 0.930 and 0.991 , respectively, indicating an excellent strength of agreement. The ICC values for the agreement of the extracts at varying $w / v$ concentrations of $0.01,0.1,0.25$, and $0.5 \%$ were $0.526,0.513$, 0.947 , and 0.975 , respectively. The strength of agreement ranged from moderate to excellent (Indrayan 2012) (Tables 1 and 2 and Figs. 3, 4, and 5).

Table 2 Intra-class correlation coefficient of the negative and positive controls and various concentrations of Clinacanthus nutans for comparative analysis of dimethylthiazol bromide and sulforhodamine B protein

\begin{tabular}{lll}
\hline Intra-class correlation coefficient & Strength of agreement \\
\hline Negative & .930 & Excellent agreement \\
Positive & .991 & Excellent agreement \\
0.01 & .526 & Moderate agreement \\
0.1 & .513 & Moderate agreement \\
0.25 & .947 & Excellent agreement \\
0.5 & .975 & Excellent agreement \\
\hline
\end{tabular}



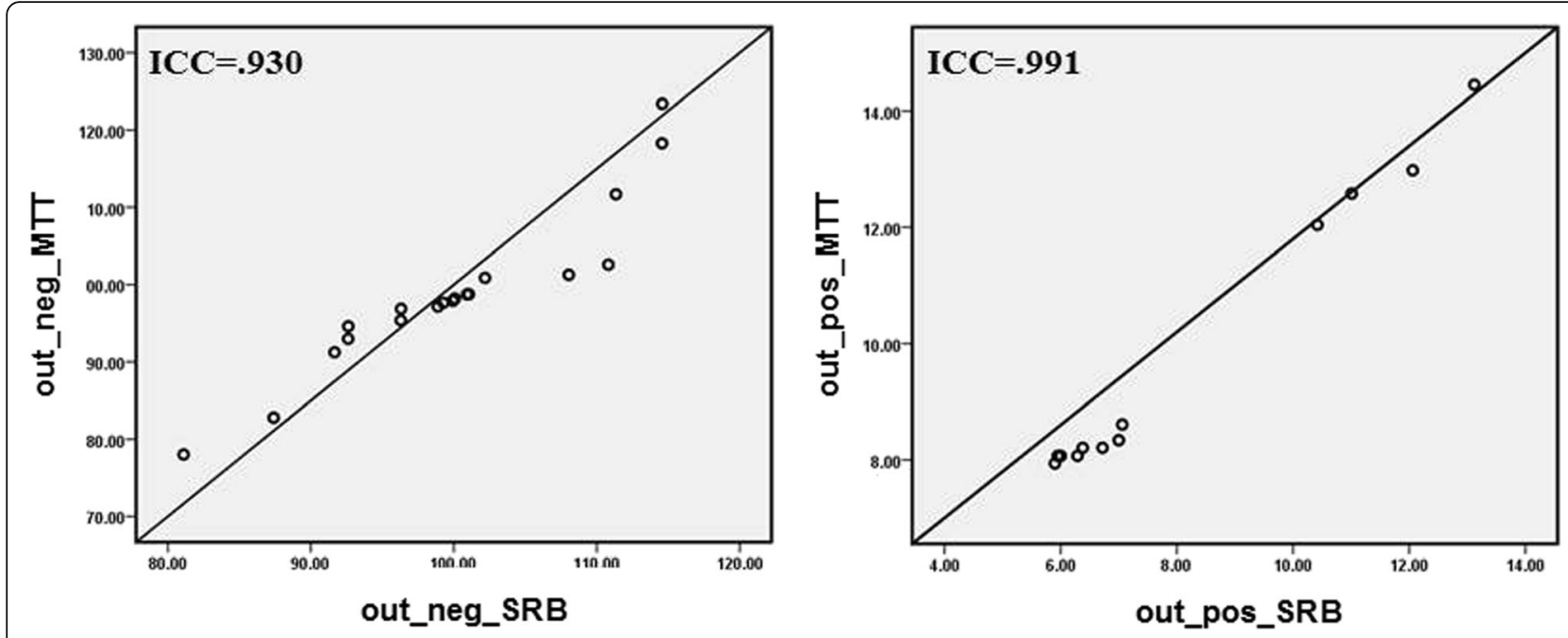

Fig. 3 Intra-class correlation coefficient values for agreement between the MTT and SRB assays in negative and positive group

\section{Discussion}

In our study, MTT and SRB assays performed similarly in the cytotoxicity evaluation of $C$. nutans. The assays had moderate correlations at the low concentrations of 0.01 and $0.1 \%$ but excellent agreement at the high concentrations of 0.25 and $0.5 \%$. The negative and positive controls exhibited excellent agreement between both assays. Our study is similar to Patel and Patel's (2011) study in which the cytotoxicity activity of a methanolic extract of Artocarpus heterophyllus was investigated using two in vitro cytotoxicity assays-MTT vs. SRB. The $\mathrm{IC}_{50}$ values of this methanolic extract were 35.26 and $35.27 \mu \mathrm{g} / \mathrm{ml}$ for MTT and SRB, respectively, in the A549 cell line $(p>0.05)$. Patel et al. (2009) also used both assays to evaluate the cytotoxicity of a Solanum nigrum methanolic extract on HeLa cells; the inhibitory concentration range for Solanum nigrum was between 10 and $0.0196 \mathrm{mg} / \mathrm{ml}$ in both assays. This study and the two studies mentioned above (Patel and Patel 2011; Patel et al. 2009) confirmed the same correlation of two assays in other cell lines besides L929 cells. Moreover, mouse fibroblast L929 is a normal cell line which is recommended by International Standard for the testing of medical devices (International Standard Organization; ISO 10993-5 2009) and responds more sensitively than primary cells (Schedle et al. 1995).

By contrast, Keepers et al. (1991) compared two assays for in vitro chemosensitivity testing of drugs with different mechanisms of action on two human tumor
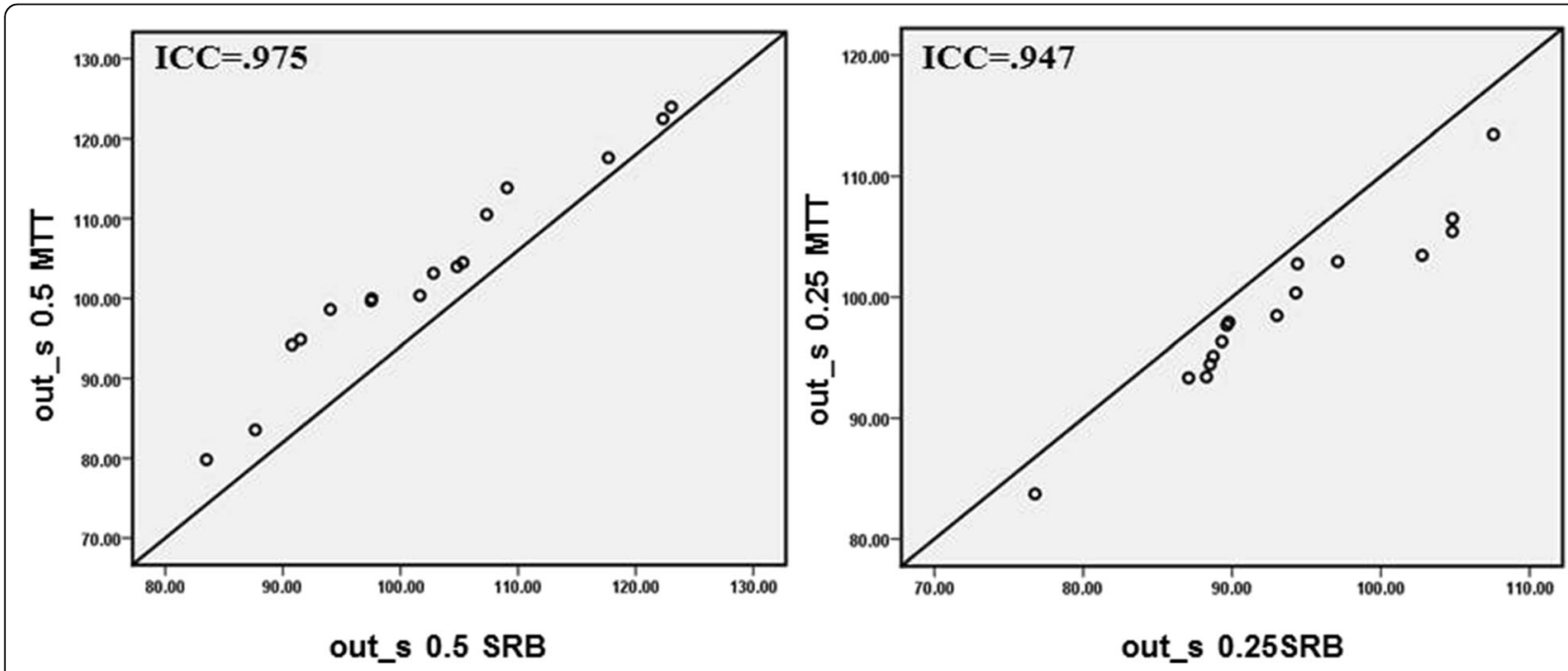

Fig. 4 Intra-class correlation coefficient values for agreement between the MTT and SRB assays at concentration of 0.5 and $0.25 \%$ 

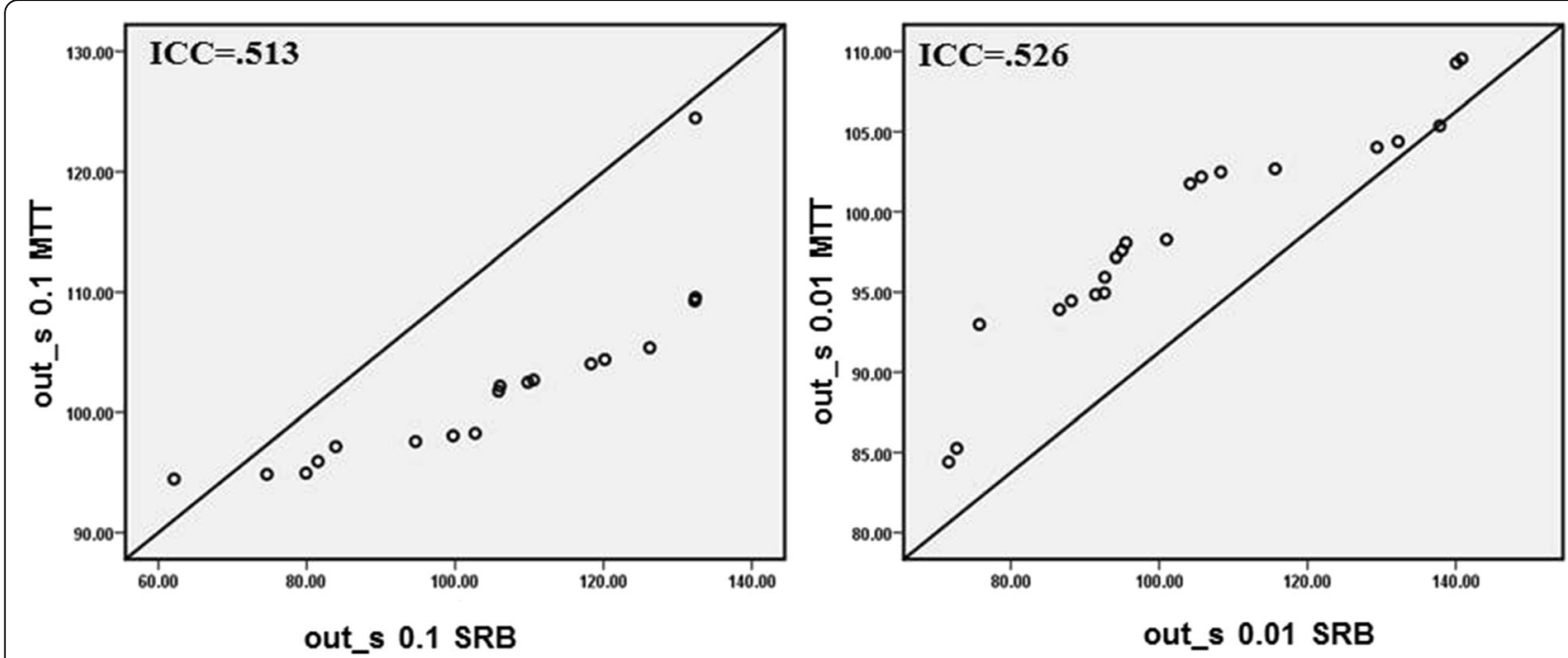

Fig. $\mathbf{5}$ Intra-class correlation coefficient values for agreement between the MTT and SRB assays at concentration of 0.1 and $0.01 \%$

cell lines-MT29 and 11B. In that study, the SRB assay had better linearity with cell number and higher sensitivity, and its staining was not cell line dependent. In contrast to the MTT assay, the SRB assay stained recently lysed cells. However, cell debris was not stained by SRB; therefore, drug sensitivity was not affected. The ${ }^{51} \mathrm{Cr}$-release method is a more sensitive cytotoxicity assay and has been modified for application to dental materials. Vajrabhaya et al. (1997) compared the SRB staining assay against ${ }^{51} \mathrm{Cr}$-release in cytotoxicity tests of six endodontic sealers. In their study, Apexit was the least toxic sealer in both assays. Since SRB staining is an easily conducted test of viability, it may become the method of choice over the ${ }^{51} \mathrm{Cr}$-release assay in the evaluation of endodontic sealer cytotoxicity.

Both assays can be used to evaluate herbal plant cytotoxicity, but each assay has some limitations. For example, MTT is categorized as a carcinogen. Thus, MTT waste must be appropriately eliminated after testing by environmental pollution control agencies. Light contamination must be prevented during SRB staining because SRB can be degraded by light exposure. Additionally, the staining process should be carefully performed within a specific time according to the manufacturer's instructions; otherwise, the protein will be washed out and result in underestimated OD.

\section{Conclusions}

Two in vitro cytotoxicity assays, MTT and SRB, were compared to determine their correlation in the cytotoxicity evaluation of a Thai herbal plant. Moderate to excellent agreement was noted for the evaluation of Clinacanthus nutans cytotoxicity. Thus, both MTT and
SRB assays can be used for cytotoxic screening of Clinacanthus nutans.

\section{Acknowledgements \\ The authors wish to thank Dr. Arthur M. Navarro of the Research Fellow Forum for Ethical Review Committees in Asia and the Western Pacific Region (FERCAP) WHO-TDR Clinical Coordination and Training Center (CCTC) Academic Affairs Building for reviewing manuscript.}

Availability of data and materials

The spectral datasets supporting the conclusions of this article are included within the article in the "Results" section.

Authors' contributions

Both authors read and approved the final manuscript.

\section{Authors' information}

Suwnnna Korsuwannawong is a senior researcher at the research office, Faculty of Dentistry, Mahidol University. Prof. La-ongthong Vajrabhaya is a Deputy Dean for Research Affairs, College of Dental Medicine, Rangsit University.

\section{Competing interests}

The authors declare that they have no competing interests.

\section{Publisher's Note}

Springer Nature remains neutral with regard to jurisdictional claims in published maps and institutional affiliations.

\section{Author details}

${ }^{1}$ Endodontics Section, College of Dental medicine, Rangsit University, Pathumtanee 12000, Thailand. ${ }^{2}$ Research Office, Faculty of Dentistry, Mahidol University, Yothi Road, Rajthawee District, Bangkok 10400, Thailand.

Received: 9 February 2018 Accepted: 8 June 2018

Published online: 13 July 2018

\section{References}

Bland JM, Altman DG. Statistical methods for assessing agreement between two methods of clinical measurement. Lancet. 1986;1:307-10.

Bland JM, Altman DG. A note on the use of the intraclass correlation coefficient in the evaluation of agreement between two methods of measurement. Comput Biol Med. 1990;20:337-40. 
Bland JM, Altman DG. Comparing methods of measurement: why plotting difference against standard method is misleading. Lancet. 1995;346:1085-7.

Deyo RA, Diehr P, Patrick DL. Reproducibility and responsiveness of health status measures: statistics and strategies for evaluation. Control Clin Trials. 1991;12:142S-58S.

Edmondson JM, Armstrang LS, Martiner AO. A rapid and simple MTT-based spectrophotometric assay for determining drug sensitivity in monolayer cultures. J Tissue Cult Methods. 1998;11:15-7.

Indrayan A. Medical biostatistics. 3rd ed. Boca Raton: Chapman \& Hall/CRC; 2012.

International Organization for Standardization; ISO 7405 (2008) Evaluation of biocompatibility of medical devices used in dentistry ISO/FDIS.

International Standard Organization; ISO 10993-5(2009) Biological evaluation of medical devices-part 5: tests for in vitro cytotoxicity.

Keepers YP, Pizao PE, Peters GJ, Van AJ, Winograd B, Pinedo HM. Comparison of the sulforhodamine B protein and tetrazolium (MTT) assays for in vitro chemosensitivity testing. Eur J Cancer. 1991;27:897-900.

Mosmann T. Rapid colorimetric assay for cellular growth and survival: application to proliferation and cytotoxicity assay. J Immunol Methods. 1983;65:55-63.

Park JG, Kramer BS, Steinberg SM. Chemosensitivity testing of human colorectal carcinoma cell lines using a tetrazolium based colorimetric assay. Cancer Res. 1987:47:5875-9.

Patel RM, Patel SK. Cytotoxic activity of methanolic extract of Artocarpus heterophyllus against A549, Hela and MCF-7 cell lines. J App Pharm Sci. 2011:1:167-71.

Patel S, Gheewala N, Suthar A, Shah A. In-vitro cytotoxicity activity of Solanum nigrum extract against Hela cell line and Vero cell line. Int J Pharm Pharm Sci. 2009;1:38-46.

Plumb JA, Milroy R, Kaye SB. Effects of the pH dependence of 3-(4,5dimethylthiazol-2-yl)-2, 5-diphenyltetrazolium bromide formazan absorption on chemosensitivity determined by a novel tetrazolium-based assay. Cancer Res. 1989;49:4435-40.

Ruben RL, Neubauer RH. Semiautomated colorimetric assay for in vitro screening of anticancer compounds. Can Treat Rep. 1987;71:1141-9.

Rubenstein LV, Shoemaker RH, Paull KD. Comparison of in vitro anticancerdrug screening data generated with a tetrazolium assay versus a protein assay against a diverse panel of human tumor cell lines. J Natl Cancer Inst. 1990:82:1113-8.

Schedle A, Samorapoompichit P, Rausch-Fan XH, Franz A, Fureder W, Sperr WR, Sperr W, Ellinger A, Slavicek R, Boltz-Nitulescu G, et al. Response of L-929 fibroblasts, human gingival fibroblasts, and human tissue mast cells to various metal cations. J Dent Res. 1995;74:1513-20.

Skehan P, Storeng P, Scudiero D. New colorimetric cytotoxicity assay for anticancer-drug screening. J Natl Cancer Inst. 1990;82:1107-12.

Vajrabhaya L, Korsuwannawong S. Cytotoxicity evaluation of Clinacanthus nutans through dimethylthiazol diphenyltetrazolium bromide and neutral red uptake assays. Eur J Dent. 2016;10:134-8.

Vajrabhaya L, Korsuwannawong S, Bosl C, Schmalz G. The cytotoxicity of selfetching primer bonding agents in vitro. Oral surg Oral Med Oral Pathol Oral radiol Endod. 2009;107:e86-90.

Vajrabhaya L, Pasasuk A, Harnirattisai C. Cytotoxicity evaluation of single component dentin bonding agents. Oper Dent. 2003a;28:440-4.

Vajrabhaya L, Sithisarn P, Wilairat P, Leelaphiwat S. Comparison between sulphorhodamine-B dye staining and 51Cr-release method in cytotoxicity assay of endodontic sealers. J Endod. 1997;23:355-7.

Vajrabhaya L, Vongphan N, Hongskul P, Kosuwannawong S. The effect of age of refrigerated conditioned medium on cell survivability in vitro. Dent Traumatol. 2003b:19:41-4.

\section{Submit your manuscript to a SpringerOpen ${ }^{\circ}$ journal and benefit from:}

- Convenient online submission

- Rigorous peer review

- Open access: articles freely available online

- High visibility within the field

- Retaining the copyright to your article

Submit your next manuscript at $\gg$ springeropen.com 